\title{
Teaching press freedom and open justice: A model for debate
}

\section{A ABSILRACIL}

This article explores ways of building the topics of press freedom and open justice into the tertiary journalism curriculum. It uses reflective practice techniques in developing a series of two by three hour workshop modules centred around introducing students to the principles of press freedom and open justice, exploring cases where these issues have been tested in the courts, and building students' skills in defending press freedom and open justice in the newsroom and the courtroom. It uses problem-based and experiential pedagogies to bring historical and philosophical principles to life and make them relevant to students' experiences and current newsroom practices. Finally, it invites comments and discussions on other curricular and pedagogical approaches to teaching these topics.

\section{MARK PEARSON}

Bond University

$\mathrm{T}$ HERE IS a salutory lesson in conducting a very simple Boolean search for the words 'press AND freedom AND education' on two or three of the leading online research indexes. Three observations stand out:

- The research is overwhelmingly American in origin;

- A surprising proportion of the articles relate to elementary and high school instruction in First Amendment principles; and

- There is evidence of enormous public and private endowments to sponsor education about freedom of the press.

Whether or not the Americans match their rhetoric on First Amendment 
rights with ongoing policy and legal commitment to press freedom is a moot point, but there is no doubt that for historical and cultural reasons the United States has fought the good fight in this regard. When we realise that press freedom forms a significant part of the school curriculum in that country (Blum, 1986; Sorenson, 1987) it underscores the challenge we face in introducing it to tertiary journalism students. The reality is that most Australians and New Zealanders could honestly say: 'I must have been away from school the day we did press freedom.' The greater shame is that many journalism graduates can probably offer the same excuse. (I must point out that my experience of journalism programmes in developing countries, particularly in the Pacific region, is that there is much more attention paid to this topic.)

\section{Literature overwhelmingly American}

And what about that sponsorship of First Amendment lobby groups, research enterprises, and educational programmes in the United States? My simple search revealed two A $\$ 3$ million grants to US universities to study press freedom issues. (Friendly, 1983; Metaxas and Kaplan, 1986). And at this point I must thank my own university for seed-funding this little piece of research to the level of $\$ 2000$. Of course, it's unfair to make such a juxtaposition, but it highlights the gulf between the US and most other developed countries in the importance placed on this topic. It is wonderful to see the University of Technology, Sydney, and the Australian Centre for Independent Journalism (at UTS) taking the initiative to invest in the public right to know by staging their annual PR2K (Public Right to Know) conferences. Nevertheless, as became clear reading the proceedings of their 2001 conference (acij.uts.edu.au/pr2k/ 2001/abstracts.html), the job is ahead of us all.

A skim through the basic research on the teaching of press freedom in tertiary journalism programmes is also enlightening. Again, the literature is overwhelmingly American, with journalism educators in other countries seemingly inclined to mention the issue only as an aside to broader discussions of the state of media law and ethics instruction (Johnston, 2002; Zanotto, 1997; Pearson, 1995). Most of the scholarship on the topic has been published in the official teaching journal of the Association for Education in Journalism and Mass Communication, Journalism and Mass Communication Educator (formerly Journalism Educator). The journal even devoted a whole themed edition in 1991 to the study and teaching of freedom of expression, which featured a 
seminal article by then Louisiana State University Professor John Merrill, who bemoaned the fact that freedom of expression was taken for granted:

The importance of free expression is taken as a given by journalism and communication students. Students come into their beginning classes spouting platitudes about freedom of the press and freedom of speech without having much, if any, background on the subject. Seldom, if ever, have they given attention to the genesis of the concepts, the limits of the concepts, or to their responsibilities and restrictions which must go along with them (Merrill, 1991: 70).

The edition featured five research articles on approaches to teaching freedom of expression in journalism and communication courses. What became obvious was that US journalism programmes typically have a full subject devoted to free press issues, titled something like 'The History and Theory of Freedom of Expression' or 'Mass Media in a Democratic Society' (Helle, 1991: 4). In Australia and New Zealand, while the issue will undoubtedly arise in the teaching of many topics throughout a journalism course, the typical formally scheduled treatment of freedom of the press will likely be in one or two weeks of a single subject such as 'Introduction to Journalism', 'Journalism History', or 'Media Law and Ethics'. I could be wrong, and I look forward to being pleasantly surprised when in 2003 I survey the way free speech and open justice are taught in this country.

The aim of this article is to consider how these topics might best be taught if they were to occupy just two weeks of classes in a busy tertiary journalism curriculum. It might sound presumptuous to predict that the topics 'Press Freedom' and 'Open Justice' might constitute two weeks of classes in a journalism course, but I can almost guarantee that some of our programmes will have exactly those topics as Weeks 3 and 4 in their Media Law subjects over the next year or so. Why? Because several of the courses use my textbook, The Journalist's Guide to Media Law, and the forthcoming second edition will cover these topics as the new Chapters 3 and 4 when it is published next year. While teachers will undoubtedly use the text in different ways, and some will not use it at all, at least some will choose to allocate a week of classes to each of these topics.

So how might they teach them, assuming they are confronted with a typical three hour teaching session each week, assuming the course is offered on 
campus, and that those three hours consist of a single hour of lecture and two hours of tutorials or seminars? (Different configurations and modes abound. Distance, particularly online delivery, offers endless possibilities, particularly if instructional designers with big budgets are available.)

\section{Topics premised on a defence of freedoms}

First, to the curriculum - the topics as covered in these chapters of the text. The chapter 'Freedom of the Press' is premised on the fact that journalists are sometimes called upon to defend their freedoms against those who are critical of the media and their operations. It aims to equip them with some basic knowledge so they are better equipped to articulate that defence. The chapter cites Socrates' death sentence for speaking out against the government in 399BC as an early example of gagged expression. It tracks press freedom through Milton's writings against the licensing of printing; Locke's adoption of the cause through his Essay Concerning Human Understanding; Defoe's and Cato's rallies against censorship; Blackstone's commentaries against 'prior restraint'; the origin of the term the 'Fourth Estate'; the shift of the battleground to the United States through the speeches of Jefferson in the lead-up to the passing of the First Amendment; John Stuart Mill's platforms for free expression in On Liberty back in Britain; and the series of US cases through the 20th century that first safeguarded then entrenched First Amendment rights. The story of colonial press censorship in Australia draws upon the accounts of early censorship by historians Henry Mayer (1964) and Robert Pullan (1994) and features the famous defence of press freedom featured in the letter from Chief Justice Francis Forbes to Governor Darling who wanted to gag the Australian and the Monitor with licencing and stamp duties acts. It then focuses on the three important phases of High Court free speech cases through the 1990s. The chapter introduces different international models of press freedom, using Siebert's Four Theories of the Press (1963) as a starting point and directs students to the web sites of several international organisations established to defend freedom of expression. Finally, it talks of the 'threat from within', the modern commercial ethic of media organisations which erodes the press's claim to special freedoms. It ends with some strategies journalists might adopt in defending media freedoms when called upon to do so.

There is a great deal to cover here. The most straightforward and traditional approach would be to have the students read the chapters before class and the 
lecturer would then deliver a single hour of monologue addressing the key points and cases mentioned in the chapter, injecting the presentation with their own views and examples, and perhaps even some new material which has come to light since the publication of the text. The tutorial could be occupied by detailed examination of the cases and animated tutor-led discussion of the students' weekly responses to the end of chapter questions:

1. What differences can you identify between freedom of speech and press freedom?

2. What other civil liberties or rights may be compromised for the sake of press freedom?

3. Is it always best that the truth is exposed? Can you think of situations where a greater public benefit arises from the truth not being disclosed?

4. Some argue that the media is 'not just another business'. What is meant by this?

5. Is the notion of the media as an independent watchdog too idealistic or outdated for the 21 st century?

6. Why are the advocates of media freedom so opposed to the exercise of 'prior restraint'?

7. Think of a situation where you have encountered censorship. Explain how it arose and the competing interests at stake.

8. The United States has the First Amendment to its Constitution enshrining free speech and press freedom. Would such a clause be suitable for Australian or New Zealand society?

9. Governments in some developing countries argue their people are not yet ready for press freedom. Think of arguments for and against this position. 10. Look at each of the points raised by Justice Ian Callinan in the Australian Broadcasting Corporation v. Lenah Game Meats Pty Ltd [2001] HCA 63 case mentioned earlier. Think of a counter-argument for each of his points. (Pearson, forthcoming.)

Chapter 4 addresses the related topic of Open Justice. Again, its aim is to equip journalists to understand the origins of this notion so they can defend it when they need to, such as when a court is about to issue a suppression order. It traces the origins of open courts back to Saxon times when the people attended court to give their verdict; the open Star Chamber of the 16th century; the commen- 
taries of Blackstone again, calling for the open examination of witnesses; 19th century scholar Jeremy Bentham's treatise on publicity of the judicial process; the classic open justice case of Scott v. Scott in 1913; Lord Hewart's pronouncement in the Sussex Justices case in 1924 that 'justice should not only be done, but should manifestly and undoubtedly be seen to be done'; and a series of Australian cases surrounding the issue of suppression orders from the Raybos case in 1985 through to the very recent cases of ASIC v. Rich in 2001 and 2002. The chapter also outlines the restrictions on special kinds of cases such as sexual assault matters, children in court, and family court. Its end of chapter questions include:

1. How has the principle of open justice become so entrenched in our system?

2. Given the number of exceptions to the principle, do you think it still has force, or has it become mere rhetoric?

3. How well might open justice hold up against the more recently valued notion of privacy?

4. Committal proceedings are just the preliminary hearings to determine whether someone should face trial. What are the arguments for and against media coverage of committal proceedings?

5. Assume you are covering a committal hearing where a local businessmen has been charged with sexual assault of an employee. The businessman denies the charge and his lawyer asks that his identity be suppressed to protect his personal reputation and good business name. What issues arise? Would your position change if it was a fraud charge rather than a sexual charge? What arguments might you raise to oppose such a suppression order? (Pearson, forthcoming).

So, there you have a curriculum for two weeks of classes, and a traditional pedagogical approach you might expect to find in a university history or law class. Many still swear by it, and generations of law students are practising today having learned the law by this method. This article is not about criticising that approach. I have written elsewhere about why journalism and law students might have different needs and require different teaching strategies (Pearson, 1995; Pearson, 2001). I have also joined others, most notably Lynette Sheridan Burns and Michael Meadows, in expounding the benefits of reflective practice or problem-based learning in journalism education (Pearson, 1994; Sheridan 
Burns, 1996; Sheridan Burns, 1997; Meadows, 1997; Pearson, 2000). For an excellent exposition of the approach you might refer to Lynette Sheridan Burns' recent book, published by Sage, titled Understanding Journalism (2002). Sheridan Burns cites the work of educationalist Donald Schön, whose research aimed to equip professionals with the ability to make crucial decisions in the midst of practice. Schön (1987:26) coined the expression 'reflection-in-action' to describe the ability of the professional to reflect upon some problem in the midst of their daily work. Journalists need this ability to reflect upon their knowledge of media law when confronted with legal dilemmas while reporting if their education in law is to be useful. Schön (1987, p.18) positions the 'reflective practicum' as the optimal mechanism for imbuing students with the 'kinds of artistry essential to competence in the indeterminate zones of practice'.

\section{A truly reflective practicum}

Given the task at hand, it may be somewhat ambitious to establish the full practicum envisaged by Schön for the sake of two three hour sessions on these topics. Nevertheless, programmes that adopt such a philosophy in full might already have such a practicum in operation, ready to accommodate these units. From time to time an opportunity arises and it takes astute and enthusiastic faculty to exploit it. This happened at the University of Wisconsin-Madison, where a full elective involving both journalism and law students was based around the coverage of an important Supreme Court free speech case involving their university. Students and staff flew to Washington to report upon the hearings for the student press, a true reflective practicum where theory and practice fed off each other to the benefit of student learning (Drechsel, 2001). Australians recently missed such an opportunity with the fascinating argument led by Geoffrey Robertson before the High Court in the Gutnick v. Dow Jones case which will determine much to do with defamatory material in online publications.

If we cannot accommodate a full practicum, at the very least we need to step back to basics and decide what it is we want students to 'reflect' about in the workplace as a result of their learning in the areas of free speech and open justice. It seems they need two competencies: a lasting knowledge of the history and historical figures involved with these principles and the ability to develop an argument for each of these principles when called upon to do so in a range of potential scenarios, perhaps including a public meeting, an editorial, a letter to 
the editor, or a submission to court or Parliament. There are countless of ways of making such a topic more interesting and achieving these goals. The literature offers some excellent ideas.

Theory does not have to be thrown out the window in adopting a reflective practice approach. Helle (1991: 4) explains that the simple use of multiple choice tests or memorising case names and outcomes is a shallow, temporary form of learning. He opts for a strategy which pits the two competing theoretical streams - libertarian (favouring individual interests) and neoliberal (favouring the public interest) - against one another through student assignments.

When the names and outcomes of individual cases are long forgotten, these students will likely still be using the theories to interpret cases decided many years hence. They will write more cogent editorials and columns, articulate more principled positions whether debating a senator or a spouse, and even be able to predict the future course of the law more capably and surely (Helle, 1991: 5).

Helle does not explain in detail how he uses these theories in his teaching, except to say that the whole course uses them as a backdrop, and cases are introduced to discussion as extolling one approach or the other.

\section{The case for a team approach}

Jolliffe (1991: 15) recommends a team approach to learning about freedom of expression. Jolliffe assigned students to work in teams to develop presentations that share their learning with others. Presentations could be in a choice of media, including videos, overheads, multi-media presentations, mock newspapers, posters, performed historical-style speeches, illustrated children's books and even a shadow puppet show. Jolliffe (pp. 16-18) explains the benefits of the team approach to learning, including valuable workplace-like socialisation; group negotiation skills; synthesis of ideas through discussion; and, perhaps most importantly, reduced marking load for teachers. Jolliffe (p. 22) navigates the perennial problem of group assessment ('I did more than she did') by requiring all students to submit an individual and peer appraisal sheet which feeds into the final grading.

Merrill (1991: 72) offers a useful variation on the team approach where he divides his classes into various teams whose task is to take on the thinking and approach of one of the famous icons of the free expression literature. They are 
divided into groups labelled 'Jeffersonians', 'Madisonians', 'Millians' and so on. Students then approach class debates and assignments from that figure's perspective, leading to an appreciation and understanding of the different thinkers on the topic.

Andsager and Ross (1999: 54) remind us that assessment of outcomes of free expression courses is just as important as the pedagogical and curricular strategies themselves. They used pre-tests and post-tests to determine whether increased attention to freedom of expression resulted in a broader understanding of First Amendment issues. To do so, they measured student support for individual and media rights across a semester where different students took three courses focussing on the topic. They called for future research comparing the effectiveness of different approaches to teaching First Amendment topics.

Some of the literature on the controversial topic of public or civic journalism underscores the need for students to be able to articulate the mission and role of journalism in the democratic process. McDevitt (2000: 41) cites the philosopher John Dewey's argument that the primary goal of education should be to help students become active citizens. McDevitt extends this to his advice on teaching civic journalism, arguing that such an approach encourages students to appreciate journalism as an expression of their citizenship. Going further, Haas (2000: 38) suggests the primary political responsibility of journalism is to nurture public participation in the democratic process. Surely, journalists must need knowledge of the evolution of press freedom and the language and rhetorical skills to debate it if they are to fulfill this important calling.

So, how has this skim of the literature guided us in our development of a prototype lesson plan for our two weeks of instruction on this topic? How can we inject some imaginative learning possibilities into a potentially droll historical mix of philosophy and jurisprudence? Here's one approach which combines some background reading, pre-testing, team work, writing, debate, and post-testing, all with a dual aim of developing students' knowledge of press freedom and open justice principles and equipping them with tools to defend them both in verbal and written forms.

\section{Week A: Press Freedom}

Lecture session (1 hour):

[Students have been assigned the chapter as reading the previous week and have been warned there will be a 20 question quiz at the start of the following week's lecture.] 
1. Administer 20-question quiz on press freedom readings.

2. Collect and go through answers to quiz / discussion. (Mark later if being used for assessment.)

3. Assign tutorial teams and tasks for this week. (Four teams per tutorial.)

Tutorial session (2 hours):

1. You and your team members are representatives of the local media in one of the following situations:

a. You are covering a city council meeting when one of the councillors moves that the media be excluded from the room for discussion of the next item relating to a rezoning application for a major development. The Mayor is chairing the meeting and invites the representatives of the media to speak in defence of remaining in the room. 'What do the media have to say about this motion?' he asks.

b. The State Premier is visiting your university and delivering a lecture to which the public and the media have been invited. He asks that his answer to a sensitive question about his re-election plans remain off the record. "I'll answer it if the media agree this will not be published or broadcast," he says. c. You are on a televised pre-election panel, 'Meet the Press', where the Police Minister announces that part of her platform will be legislation banning the media from approaching within 100 metres of a crime or accident scene. 'What do our media representatives have to say to that proposal,' the host asks.

d. You are in the audience for a Chamber of Commerce luncheon where the speaker, a law professor, calls for new laws to give the Australian Press Council the power to jail or fine journalists for their ethical breaches. 'Professor Smith is now prepared to field questions or comments,' the Master of Ceremonies announces.

In each of the above scenarios another member of the class is invited to take on the role of the antagonist speaker, responding to the journalists' objections. The tutor might chair the session. Each segment can take up to 20 minutes.

10 minute mid-seminar break.

2. Explain the individual written exercise to cap this off, with students taking 10 minutes to start planning this and discussing strategies with the tutor. Task: Write a 500 word editorial for your local newspaper putting the free press arguments which stem from one of the above scenarios. Due within 24 
hours, perhaps as a minor assessment item worth, say, $10 \%$ of the semester grade.

3. Final 10 minutes spent previewing reading and quiz preparations for next week's topic on Open Justice.

\section{Week B: Open Justice}

Lecture session (1 hour):

[Students have been assigned the chapter as reading the previous week and have been warned there will be a 20 question quiz at the start of the following week's lecture.]

1. Administer 20-question quiz on Open Justice chapter contents.

2. Collect and go through answers to quiz / discussion. (Mark later if being used for assessment.)

3. Assign case report pairs and debate teams for this week. (Four teams per tutorial.)

Tutorial session (2 hours):

Hour 1: Pairs have been assigned to go to the Law Library and read one of the several cases on suppression orders and access to court documents mentioned in the chapter.

For pre-tutorial homework, each pair is to have written a submission to the court as to why they as media representatives should be granted access to the particular court documents or why a suppression order should be lifted.

Each pair is to present this to the class after summarising the case to which they have been assigned. Discussion should centre around their approaches. (Assessment optional here.)

Hour 2: Debate. Topic: 'That the names of sexual assault complainants should be publishable in the media.'

Half of the tutorial group is the For team, half the Against team.

They have 15 minutes to brief their speakers and 30 minutes to debate the issue. Allow final 10 minutes for debriefing.

Advise students there will be a 20 minute post-test on the two modules at the start of the next week's lecture. This gives faculty the opportunity to assess acquired factual knowledge, particularly given pre-session tests stand as points of comparison. (Suggested assessment for post-test $=10$ per cent of overall mark for subject.) 


\section{Conclusion}

There are, of course, many other pedagogies which could be used to achieve similar ends. Magistrates, judges, media lawyers, or articulate editors could be invited as guests and subjected to a press conference situation. Students could be assigned to interview such people, or even to interview journalists faced with such dilemmas. Or perhaps even an erudite professor with a passion for the topic could spend the lecture hour expounding upon press freedom and open justice to the delight of an entranced lecture hall, with the knowledge examinable at the end of the semester. Most of us as undergraduates were touched in such a way by at least some such awe-inspiring figures who could hold captive a teenage audience with their sheer intellect and command of the topic. I still hold vivid memories of a lecture on Australian history by Manning Clark, one on national identity by Donald Horne, several on the mass media by Henry Mayer, and weekly tutorials on Australian literature in the office of Leonie Kramer.

Nevertheless, this modest attempt at developing a prototype for delivering an informed and testable module on press freedom and open justice will hopefully spark debate on the way such topics can be accommodated in the curriculum and delivered to students. A byproduct might be that journalism educators might adopt similar strategies to re-examine or justify the teaching of other topics in their curricula.

\section{References}

Andsager, Julie, and Ross, Susan Dente. (1999, Winter). Assessment of outcomes of free expression courses. Journalism and Mass Communication Educator. 53 (4): pp. 54-65.

Blum, Ann. (1986, Spring). Fundamental freedoms: come to the First Amendment fair. (grade level: secondary) (lesson plan) Update On Law-Related Education, 10 (2): p. 5.

Drechsel, Robert E. (2001, Autumn). The 'Southworth Project'. A collaborative approach to teaching judicial reporting. Journalism and Mass Communication Educator. 56 (3): pp. 61-71.

Friendly, Jonathan. (1983, October 14). Columbia gets gift for Center on a Free Press: receives $\$ 3$ million for studying broad areas. The New York Times. 133: p.16(N) pB4 (11) col 1.

Haas, Tanni. (2000, Autumn). Public journalism challenges to curriculum and instruction. Journalism and Mass Communication Educator. 55 (3): pp. 27-41.

Helle, Steven. (1991, Summer). A theoretical framework for media law courses. Journalism Educator, 46 (2): pp. 4-14. 
Hentoff, Nat. (1991, November 26). Schools do a miserable job teaching the First Amendment. Los Angeles Daily Journal, 104 (235): p. 6

Johnston, Jane. (2002, July). Shall we dance: Who's leading whom in the journalismjustice shuffle? Australian Journalism Review. 24 (1): pp. 131- 140.

Jolliffe, Lee B. (1991, Summer). Industry's team approach to classroom projects. Journalism Educator, 46 (2): pp. 15-24.

Mayer, Henry (1964). The Press in Australia. Melbourne: Lansdowne Press.

McDevitt, Michael. (2000, Summer). Teaching civic journalism: Integrating theory and practice. Journalism and Mass Communication Educator, 55 (2): pp. 40-49.

Meadows, Michael. (1997, July). Taking a problem-based learing approach to journalism education. Asia Pacific Media Educator, 3.

Merrill, John. (1991, Summer). Teaching free expression in word and example. Autonomous decisions with necessary restraint. Journalism Educator, 46 (2): pp. 70-73.

Metaxas, John C. and Kaplan, David A. (1986, August 11). U. Va. receives $\$ 3$ million gift to study the First Amendment. The National Law Journal, 8: p.10.

Mill, John Stuart (1991). On Liberty and Other Essays. Oxford: Oxford University Press.

Pawlak, Frank. (1980, Spring). Teaching about free speech for students. Update On Law-Related Education, 4 (2): p. 8.

Pearson, Mark. (1994). Re-thinking quality in journalism education. Australian Journalism Review, 16 (2).

Pearson, Mark. (1995). Teaching media law to journalism students: Different needs, different strategies. Legal Education Review. 6 (1): pp. 37-51.

Pearson, Mark. (1997). The Journalist's Guide to Media Law. Allen \& Unwin: Sydney.

Pearson, Mark. (2000, January-June). 'Reflective Practice In Action: Preparing Samoan Journalists To Cover Court Cases'. Asia-Pacific Media-Educator, 8.

Pearson, M. (2001.) A question of legality. In S. Tapsall \& C. Varley (eds) Journalism Theory and Practice, Oxford University Press: South Melbourne.

Pearson, Mark. (forthcoming). The Journalist's Guide to Media Law. 2nd edition. Allen \& Unwin: Sydney.

Pullan, Robert. (1994). Guilty Secrets. Free Speech and Defamation in Australia. Glebe: Pascal Press.

Schön, Donald. (1987) Educating the reflective practitioner. Toward a new design for teaching and learning in the professions. San Francisco: Jossey-Bass.

Schroth, Monica (2000, Spring). Reckless aiding and abetting: sealing the cracks that publishers of instructional materials fall through. Southwestern University Law Review, 29 (3): pp. 567-616.

Sheridan Burns, Lynette. (1996). Blocking the exits: focus on the decision in ethical decision-making. Australian Journalism Review, 18 (1): pp. 87-99. 
Sheridan Burns, Lynette. (1997). Problem-based learning: is it new jargon for something familiar? Australian Journalism Review, 19 (1): pp. 59-72.

Sheridan Burns, Lynette. (2002). Understanding journalism. Sage: London.

Siebert, Frederick S., Theodore Peterson, and Wilbur Schramm. (1963). Four Theories of the Press. Urbana: University of Illinois Press.

Sorenson, Donna. (1987, Winter). Liberty: introducing the First Amendment. (grade level upper elementary/middle) (lesson plan). Update On Law-Related Education, 11 (1): p. 25.

Staten, Clifford L. (1993, January). Teaching the First Amendment to 7th and 8th graders. (Classroom Teacher's Idea Notebook). Social Education, 57 (1): p. 43.

Weiner, Merle H. (1999, Spring). Dirty words in the classroom: teaching the limits of the First Amendment. Tennessee Law Review, 66 (3): pp. 597-685.

Zanotto, Jeanete. (1997, June). Journalism law curriculum in the 1990s: Balancing practical and theoretical content. Australian Journalism Review. 19 (1): pp. 99-104.

Dr Mark Pearson is professor and head of journalism, Bond University, Queensland. An earlier version of this article was presented to the Public Right To Know Conference, University of Technology, Sydney, 14-15 September 2002. The author wishes to thank panelists and delegates to that conference and the peer reviewers from PJR for theirfeedback and the Bond University School of Humanities and Social Sciences for funding the research upon which the paper was based.

Mark_Pearson@bond.edu.au 